Article

\title{
The Potential Role of Ammonia as Marine Fuel-Based on Energy Systems Modeling and Multi-Criteria Decision Analysis
}

\author{
Julia Hansson ${ }^{1,2, *}$, Selma Brynolf ${ }^{1}$, Erik Fridell ${ }^{2}$ and Mariliis Lehtveer ${ }^{3}[$ \\ 1 Department of Mechanics and Maritime Sciences, Maritime Environmental Sciences, Chalmers University of \\ Technology, SE-412 96 Gothenburg, Sweden; selma.brynolf@chalmers.se \\ 2 Sustainable Society, IVL Swedish Environmental Research Institute, Box 530 21, SE-400 14 Gothenburg, \\ Sweden; erik.fridell@ivl.se \\ 3 Department of Space, Earth and Environment, Energy Technology, Chalmers University of Technology, \\ SE-412 96 Gothenburg, Sweden; mariliis.lehtveer@chalmers.se \\ * Correspondence: julia.hansson@ivl.se
}

Received: 15 March 2020; Accepted: 15 April 2020; Published: 17 April 2020

check for updates

\begin{abstract}
To reduce the climate impact of shipping, the introduction of alternative fuels is required. There is a range of different marine fuel options but ammonia, a potential zero carbon fuel, has recently received a lot of attention. The purpose of this paper is to assess the prospects for ammonia as a future fuel for the shipping sector in relation to other marine fuels. The assessment is based on a synthesis of knowledge in combination with: (i) energy systems modeling including the cost-effectiveness of ammonia as marine fuel in relation to other fuels for reaching global climate targets; and (ii) a multi-criteria decision analysis (MCDA) approach ranking marine fuel options while considering estimated fuel performance and the importance of criteria based on maritime stakeholder preferences. In the long-term and to reach global GHG reduction, the energy systems modeled indicate that the use of hydrogen represents a more cost-effective marine fuel option than ammonia. However, in the MCDA covering more aspects, we find that ammonia may be almost as interesting for shipping related stakeholders as hydrogen and various biomass-based fuels. Ammonia may to some extent be an interesting future marine fuel option, but many issues remain to be solved before large-scale introduction.
\end{abstract}

Keywords: shipping; alternative fuels; ammonia; decarbonization; biofuels; greenhouse gas emission targets; scenarios; multi-criteria decision making

\section{Introduction}

In 2018, the International Maritime Organization (IMO) agreed to reduce greenhouse gas (GHG) emissions from international shipping by at least $50 \%$ by 2050, phase them out by 2100 at the latest, and to reduce the carbon dioxide $\left(\mathrm{CO}_{2}\right)$ emissions per transport work by $40 \%$ in 2030 and $70 \%$ in 2050 , relative to 2008 [1]. To reach these objectives, the conventional use of fossil fuels needs to be drastically reduced and combined with the introduction of operational and technical measures that reduce fuel consumption in combination with the introduction of energy carriers with low or near zero GHG emissions [2-7].

There is a range of different marine fuel options with varying characteristics in terms of, for example, availability, cost, energy density, technical maturity, and environmental impact $[2,8,9]$. In recent years, ammonia has been proposed as a potential marine fuel that would give no emissions of $\mathrm{CO}_{2}$ from the ship since it is a carbon-free molecule [8,10-14]. 
Ammonia $\left(\mathrm{NH}_{3}\right)$ produced from hydrogen and nitrogen may thus contribute to low climate impact if produced from renewable energy sources (or combined with carbon capture and storage, CCS). However, ammonia is currently mainly produced from fossil fuel-based hydrogen while production processes for renewable ammonia are still under development $[15,16]$.

Ammonia, as energy carrier, can, with the development of existing technologies, be used in fuel cells or in internal combustion engines (ICE). There are some scientific papers assessing ammonia as transport fuel. For example, Kang and Holbrook [17] assessed the GHG reduction potential of introducing ammonia fueled light-duty vehicles in the US transportation sector to 2040. For shipping, some studies have applied multi-criteria decision analysis (MCDA) to assess and rank selected marine fuel options, for example liquefied natural gas (LNG), fossil methanol, and hydrogen $[9,18-20]$. However, while Hansson et al. [9] included several renewable options, none of these studies include ammonia.

By developing decarbonization pathways for international shipping that combine different technologies including ammonia as fuel, Halim et al. [21] assess the possible $\mathrm{CO}_{2}$ reduction potential by 2035 . The study assumes in some cases that hydrogen and ammonia may represent about $70 \%$ or more of the total marine fuel demand in 2035 [21]. Ben Brahim et al. [22] presented pathways to climate-neutral shipping by 2050 for the Danish maritime cargo sector and found that hydrogen, methanol, and ammonia are the most preferable from a socioeconomic cost perspective. However, to assess the potential role of ammonia as marine fuel in the future, there is a need for more studies clarifying the knowledge gaps and its prerequisites in relation to other options, for example when considering also other energy demand sectors and several other criteria such as safety, distribution, and development of engines/fuel cells.

The aim of this paper is to assess the prospects for ammonia as a future fuel for the shipping sector in relation to other marine fuel options. The paper includes a synthesis of knowledge on ammonia as an alternative marine fuel, which is used partly as basis for: (i) an assessment of the cost-effectiveness of ammonia as marine fuel for reaching global climate targets using energy systems modeling; and (ii) a multi-criteria decision analysis (MCDA) resulting in a ranking of different marine fuels.

From an overall point of view, this paper discusses prospects for ammonia as marine fuel with a broader perspective and in more detail than many other studies. In the long-term and to reach global GHG reduction, the energy systems modeled in this paper indicate that the use of hydrogen represents a more cost-effective option for the shipping sector than ammonia. However, in the MCDA covering more aspects, we find that ammonia may be almost as interesting for shipping related stakeholders as hydrogen and various biomass-based fuels. Due to primarily the potential low climate impact, ammonia has potential as future marine fuel, but many issues remain to be solved before it can be introduced in large-scale and more detailed additional assessments and comparisons are needed.

\section{Materials and Methods}

Initially, a literature review on ammonia covering for example production pathways, costs, and environmental impact was performed. Based on this the prospects for ammonia as marine fuel in relation to other fuel options were then assessed by: (i) energy systems modeling of the cost-effectiveness of ammonia as marine fuel compared to other alternative marine fuel options for reaching global climate targets; and (ii) applying a multi-criteria decision analysis (MCDA) approach that is based on the estimated fuel performance and on input from a panel of maritime stakeholders with varying preferences.

\subsection{Ammonia as Fuel—A Brief Synthesis of Knowledge}

Approximately $80 \%$ of the total global ammonia consumption is used in the production of fertilizers, such as urea, ammonium nitrate, ammonium phosphate, or direct use of ammonia while the rest is used in various industrial applications, e.g., explosives, healthcare, cosmetic, animal nutrition, nutrition, plastics, resins, and electronics, as well as in $\mathrm{NO}_{\mathrm{X}}$ control systems in the automotive industry [16,23]. The global production amounted to approximately 180 million tons in $2016[16,23]$. 
Ammonia is currently produced mainly by the electricity demanding Haber-Bosch (HB) process and the nitrogen used is produced from air via the reforming step or by a separate air separation process [16,24].

Besides fossil fuels, hydrogen can also be produced from reforming biogas and renewable methane or from electrolysis of water using renewable energy sources, e.g., wind, solar, and water power. Electrochemical synthesis, where ammonia is synthesized in a single electrochemical reactor using water or steam, nitrogen, and electricity, represents another possible ammonia production pathway with for example potentially reduced energy use [25]. However, further development is needed to obtain ammonia production rates high enough for commercialization for this process $[16,25,26]$. A technology representing an integration of the electrolyzer and the HB units, without the need for an air separation unit is also being developed by Haldor Topsoe potentially resulting in reduced cost and energy use [27].

Globally, there are several initiatives for production of renewable ammonia. For example, the ammonia producer Yara plans to build a demonstration plant for ammonia from solar energy in Australia and Haldor Topsoe aims to demonstrate its next-generation green ammonia synthesis plant (using a solid oxide electrolysis cell) by $2025[27,28]$.

\subsubsection{Ammonia Fuel Performance}

Ammonia has been demonstrated as a fuel in compression ignition (CI) engines, spark ignition (SI) engines, and fuel cells [29-34]. A recent review of the literature on engine tests with ammonia shows that there are a limited number of tests published on ammonia in combustion engines and that significant amounts of ignition fuel (e.g., hydrogen, diesel, or alcohols) are needed for both CI and SI engines [35]. The review concludes that there are remaining issues with ignition, specific fuel consumption, materials, and emissions [35]. Besides ammonia slip, there are potential emissions of $\mathrm{NO}_{X}, \mathrm{CO}$, hydrocarbons (depending on pilot fuel), and $\mathrm{N}_{2} \mathrm{O}$, even if it seems likely that these emissions can be handled with after treatment further assessments are needed.

In fuel cells, either ammonia can be used directly or ammonia is split into hydrogen and $\mathrm{N}_{2}$ and the hydrogen then used in the fuel cell. Two fuel cell options that may be used in marine applications are proton-exchange membrane fuel cells (PEM) using purified hydrogen and solid oxide fuel cells (SOFC) using ammonia [36]. PEM fuel cells are commercial and tested in marine applications [37]. Fuel cells using ammonia directly, besides SOFC also, e.g., alkaline and alkaline membrane, are under development [31]. No reports from tests onboard vessels have been found, but SOFC using methanol and methane have been tested [37].

Ammonia linked to fuel cells might compared to combustion engines potentially offer higher thermal efficiencies, less noise, and lower emissions of air pollutants. However, the emissions associated with ammonia fuels cells need to be confirmed. There is for example a risk for NOx emission [31]. The ammonia fuel cell pathway might also be relatively costly.

No ammonia driven propulsion technologies for marine operation have been commercialized yet. However, there are initiatives; for example, MAN Energy solutions claim that their dual-fuel engine developed for LPG may use liquid ammonia in a dual fuel setup [38]. MAN Energy solutions together with Shanghai Merchant Ship Design \& Research Institute (SDARI) and American Bureau of Shipping (ABS) also has a development project for an ammonia-fueled feeder container vessel intended to use this technology. There is also an EU funded project, ShipFC, that aims to convert an offshore vessel to run on an ammonia fuel cell.

Ammonia is a toxic substance. Ammonia released into the atmosphere in high concentrations provides health risks and is lethal over certain concentrations and time periods. It may also contribute to formation of secondary particles. Ammonia is toxic for organisms living in water with potential long-term effects mainly in the case of direct exposure [11,28,36]. Ammonia in water will be converted into ammonium ions [36]. Ammonia released in the air will due to its lower density dilute and evaporate upwards; however, several factors influence how fast and to what extent ammonia diffuses 
in the air [28]. Ammonia may, for example, also, as many other fuels, form explosive mixtures with air and hydrogen from cracked ammonia is a very flammable gas [36].

Leakage and potential exposure to humans and the environment (including aquatic life) represent key safety issues linked to ammonia used as marine fuel and specific safety regulations will be needed.

Ammonia is corrosive and this need to be considered in the design of marine fuel systems [38]. The safety regulations and associated safety measures will influence the fuel handling system for bunkering and during operation, likely increasing the cost but potentially also the use of the space on-board $[24,35,36]$.

\subsubsection{Potential Cost and Supply}

From 2016 to mid-2019, the global ammonia price corresponded to a range of about 10-20 USD/GJ (using a lower heating value of $18.8 \mathrm{MJ} /$ ton for ammonia) [39]. The production cost for renewable ammonia was estimated to range within about 7-23 USD/GJ ammonia by Tun et al. (2014) and in a forthcoming study by Hochman [40] the cost of renewable ammonia production in 2040 amounts to approximately 20 and 25-35 USD/GJ for electrochemical ammonia production and electrolysis of water followed by the HB synthesis in large and small scale, respectively.

The additional propulsion system cost for an ammonia-fueled vessel with an internal combustion engine has been estimated to approximately $2-60 \%$ compared to a conventional HFO-fueled vessel and in the case of fuel cells $8-300 \%$ due to large uncertainties about requirements [14].

Ammonia is more energy dense than compressed hydrogen and liquid hydrogen. It is normally stored in insulated pressurized tanks, which require larger space requirement onboard ships than LNG and methanol [8]. However, there is no need for cryogenic storage, which is required for liquefied hydrogen [10].

There does not seem to be any main issues with fuel infrastructure or bunkering related to ammonia as marine fuel. However, a well-functioning fuel infrastructure and bunkering systems need to be implemented.

In terms of reliable supply of fuel in order for ammonia to be used as marine fuel, the global production needs to be increased, in particular from renewable sources. This will require large amounts of electricity, but the production is not constrained by any other raw materials. For comparison, the current total global ammonia production could replace about $30 \%$ of the global shipping fuel consumption if assuming equal efficiencies when used in ship propulsion systems (calculated using $[16,23,41])$.

\subsection{Energy Systems Modeling}

The cost-effectiveness of ammonia compared to other alternative marine fuel options for reaching global climate targets is performed using energy systems modeling with the Global Energy Transition (GET) Model version 10.0 [42]. The GET model has in this study been developed by adding ammonia as marine fuel.

\subsubsection{Model Structure and Main Assumptions}

GET is a cost minimizing "bottom-up" systems model of the global energy system constructed as a linear programming problem with 10-year time steps and divided into 10 regions. The GET model is used to study various carbon mitigation strategies and the objective is to minimize the discounted total energy system cost for the studied period (in our case, 2010-2100) while meeting an externally defined energy demand and a carbon constraint [42]. The carbon constraint is in the form of a carbon budget corresponding to a maximum atmospheric $\mathrm{CO}_{2}$ concentration by the year 2100 . The model has a supply side focus but has five end use sectors covering electricity, transport, residential-commercial heat, industrial process heat, and feedstock.

In the GET-model, the included primary energy sources (primarily coal, oil, natural gas, nuclear, wind, hydro, solar energy, and biomass) are by different technologies converted into secondary energy 
carriers (e.g., heat, electricity, and different transport fuels), used to supply the energy demand in the different sectors. Thus, the demand in each sector can be met by various technologies that are assumed to be available in all ten regions.

All the technologies are described by the energy carriers they can convert and estimates of their individual characteristics, e.g., costs (expressed in real terms), efficiencies, carbon emissions, and load factors. Scarcity of relevant resources, e.g., oil and biomass, are considered by maximal supply levels and are allocated endogenously to fulfill the demand in the sectors where the model finds it most cost-effective to use them. Carbon capture and storage (CCS) for stationary combustion of fossil fuels and biomass is included and linked to a maximum carbon storage capacity [42]. This applies also for fossil fuel-based ammonia production for which this option is available at a cost.

Scenarios for the demand in the different sectors, except transport, are based on the B2 scenarios from the IIASA GGI Scenario Database (for details, see Lehtveer et al. [42]). Transport includes demand for freight and personal transportation. For transport demand scenarios used for road, train, and aviation, see Grahn et al. [43]. Shipping is described in the next section. To better describe the real world, there are constraints included in the model on, e.g., how rapidly technologies can be introduced and expanded in the system (generally representing a turnover of 50 years for the entire system) and maximal extraction limits for the included energy sources.

The net present value calculations include a global discount rate of $5 \%$ per year. Since perfect foresight is assumed, the GET model identifies the least-cost solution for the entire period included in the assessment. The solutions for each region are aggregated to represent global results.

As with all models, the GET model represents a simplified description of the real energy system, for example by basing choices only on cost-effectiveness and perfect foresight, considering a limited number of technologies, and assuming a price inelastic demand. The model cannot be used to predict the future but is used to produce scenarios and assess the potential role of different options in relation to the development for other options in a carbon constrained world, potentially providing useful insights for industry, researchers, and policy makers.

\subsubsection{Marine Fuel Options and Climate Targets}

The marine fuel options included in the model are marine gas oil (MGO) and heavy fuel oil (HFO), liquefied natural gas (LNG), methanol (MeOH), hydrogen, and ammonia. For several of the fuels, different production pathways are possible. Methanol is used as a proxy for: (i) several different biofuels but represented by the characteristics of biomass-based methanol; (ii) fossil fuel-based methanol; and (iii) different kinds of electrofuels that are represented by the characteristics of the electro-methanol pathway. Electrofuels are fuels produced from $\mathrm{CO}_{2}$ and water using electricity. Hydrogen can be produced from natural gas, biomass, or through electrolysis using electricity.

Ammonia is assumed to be produced by the HB process with nitrogen and hydrogen as feedstock, and thus requires the production of hydrogen through any of the possible pathways included. A conversion efficiency of the HB process of $74 \%$ is assumed and the process is assumed to be used $80 \%$ of the year. The current investment cost for ammonia production is estimated as $2100 \mathrm{USD} / \mathrm{kW}$ and is assumed to decrease to $1900 \mathrm{USD} / \mathrm{kW}$ in 2050 [42].

Onboard the ship, the fuels can be used in internal combustion engines (ICE) or fuel cells (FC). Thus, hybrid and electric engines are not considered in this study.

In the GET model, the shipping sector is divided in three ship categories: (i) short sea ships; (ii) deep sea ships; and (iii) container ships. The ship cost consists of the construction cost that depends on the cost of engines, fuel tanks, and other extra costs such as pipeline and gas alarm system. The propulsion efficiency of the ship depends on the ship type. The ship characteristics and the cost for the ammonia propulsion technologies included are presented in Table 1. A 30-year lifetime is assumed for all ship types.

For technology performance and costs of marine fuels besides ammonia, see Lehtveer et al. [42] and Taljegard et al. [6]. The total fuel cost is calculated based on the primary energy cost, engine 
and other investment cost, conversion efficiency, capacity factor, operation and maintenance cost, distribution cost, and scarcity rent.

Table 1. Characteristics and costs for the propulsion technologies for ammonia for the three ship categories in 2050, based on estimates by Lövdahl and Magnusson [44] and Taljegard et al. [6].

\begin{tabular}{|c|c|c|c|c|}
\hline Characteristics & Unit & Short Sea Ship & Deep Sea Ship & Container Ship \\
\hline Engine power & $\mathrm{kW}_{\text {output }}$ & 2400 & 11,000 & 23,000 \\
\hline Voyage range full speed & h & 162 & 720 & 360 \\
\hline Tank capacity & GJ & 3500 & 71,300 & 74,600 \\
\hline ICE engine cost ${ }^{1}$ & USD/kW output & 800 & 600 & 600 \\
\hline ICE propulsion efficiency ${ }^{1}$ & $\%$, LHV & 45 & 40 & 40 \\
\hline FC stack cost ${ }^{2}$ & USD/kW output & 925 & 925 & 925 \\
\hline FC propulsion efficiency & \% LHV & 45 & 60 & 45 \\
\hline Storage cost ${ }^{3}$ & USD/GJ & 55 & 35 & 35 \\
\hline SCR cost for ICE & USD/kW output & 133 & 133 & 133 \\
\hline
\end{tabular}

Our assessments are made with two different climate scenarios, 450 and $550 \mathrm{ppm}$. This means that we apply cumulative carbon emission constraints that correspond to atmospheric $\mathrm{CO}_{2}$ concentrations in 2100 of 450 and $550 \mathrm{ppm}$ roughly corresponding to $70 \%$ and $50 \%$ likelihood of keeping the global average warming below $2{ }^{\circ} \mathrm{C}$. The model considers $\mathrm{CO}_{2}$ emissions and methane leakage from the use of gas in engines (at $2 \%$ ) is included as $\mathrm{CO}_{2}$ equivalents.

\subsubsection{Sensitivity Assessment: Monte Carlo Analysis}

Cost developments (linked to fuel and propulsion technology and infrastructure) and other characteristics for new marine fuels are uncertain. In our assessment, key parameters include: (i) the investment costs for ammonia synthesis (including nitrogen generation) in 2050; (ii) the efficiency of ammonia synthesis; and (iii) the additional cost for different vessels compared to conventional marine gas oil fueled ships, which depend on engine cost, fuel cell cost, and additional storage cost. To confirm our findings related to ammonia as marine fuel, a Monte Carlo (MC) analyses, in which the values of these key parameters are varied within specific intervals, are performed. The intervals used for each parameter in the MC analysis are presented in Table 2. The parameter values are varied simultaneously and uniformly within these intervals for 100 model runs. The climate target is set to $450 \mathrm{ppm}$ of $\mathrm{CO}_{2}$ for the MC analysis.

Table 2. Intervals used for the Monte Carlo sensitivity analysis. The parameter values are varied simultaneously and uniformly within these intervals for 100 model runs. For assumptions and underlying references, see Lövdahl and Magnusson [44].

\begin{tabular}{ccccc}
\hline Parameters Changed & Unit & Minimum Value & Base Case Value & Maximum Value \\
\hline $\begin{array}{c}\text { Efficiency of ammonia } \\
\text { production }\end{array}$ & $\%$, LHV & $68 \%$ & $74 \%$ & $80 \%$ \\
$\begin{array}{c}\text { Ammonia production } \\
\text { investment cost }\end{array}$ & USD/kW & 1700 & 1900 & 2100 \\
$\begin{array}{c}\text { Additional cost compared to } \\
\text { conventional MGO ship for }\end{array}$ & kUSD/ship & & & 2800 \\
different ship types: & & & 1500 & 2800 \\
MGO FC Container ship & & 200 & 1500 & 2900 \\
MeOH FC Container ship & & 200 & 1600 & 3000 \\
Bio FC Container ship & & 300 & 1700 & 3100 \\
LNG FC Container ship & & 100 & 2200 & 2800 \\
H FC Container ship & & 200 & 1500 & 1400 \\
$\mathrm{NH}_{3}$ FC Container ship & & 800 & 1100 & \\
$\mathrm{NH}_{3}$ ICE Container ship & & & & \\
\hline
\end{tabular}


Table 2. Cont.

\begin{tabular}{|c|c|c|c|c|}
\hline Parameters Changed & Unit & Minimum Value & Base Case Value & Maximum Value \\
\hline MGO FC Deep sea ship & & 1000 & 7000 & 13,000 \\
\hline MeOH FC Deep sea ship & & 1000 & 7000 & 13,000 \\
\hline Bio FC Deep sea ship & & 2000 & 8000 & 14,000 \\
\hline LNG FC Deep sea ship & & 3500 & 10,000 & 16,500 \\
\hline $\mathrm{H}_{2}$ FC Deep sea ship & & 12,000 & 16,000 & 20,000 \\
\hline $\mathrm{NH}_{3}$ FC Deep sea ship & & 1000 & 8000 & 15,000 \\
\hline $\mathrm{NH}_{3}$ ICE Deep sea ship & & 5000 & 6000 & 7000 \\
\hline MGO FC Short sea ship & & 200 & 1600 & 3000 \\
\hline MeOH FC Short sea ship & & 200 & 1600 & 3000 \\
\hline Bio FC Short sea ship & & 300 & 1500 & 2800 \\
\hline LNG FC Short sea ship & & 400 & 1700 & 3000 \\
\hline $\mathrm{H}_{2}$ FC Short sea ship & & 400 & 1800 & 3200 \\
\hline $\mathrm{NH}_{3}$ FC Short sea ship & & 200 & 1600 & 3000 \\
\hline $\mathrm{NH}_{3}$ ICE Short sea ship & & 1200 & 1500 & 1800 \\
\hline
\end{tabular}

\subsection{Multi-criteria Decision Analysis}

The range of MCDA methods is used to find the optimal and most consensual solution while considering both qualitative and quantitative information and stakeholders' preferences to different extent. The multi-criteria decision analysis approach based on the Analytic Hierarchy Process (AHP) and set up applied by Hansson et al. [9] is adapted and used in this study. This approach combines estimated fuel performance and input on criteria importance from a panel of maritime stakeholders.

AHP is chosen due to its strengths in combining quantitative and qualitative input data while specifically considering the views of different stakeholders and since it has been used in other studies of alternative marine fuels [9,18-20]. The chosen approaches rank marine fuel options based on their relative performance for included criteria and the relative importance of the criteria considering stakeholder preferences providing weights, in both cases by applying pairwise comparisons and resulting in pairwise comparison matrices [46,47]. For a more detailed description of the method used, see below and further in Appendix A and Hansson et al. [9].

The main difference to the assessment by Hansson et al. [9] is that two production pathways for ammonia are included as fuel option both for ICEs and fuel cells in ships (i.e., four more options).

\subsubsection{Marine Fuel Options and Criteria}

In total, 11 alternative marine fuel options-liquefied natural gas (LNG), liquefied biogas (LBG, from organic waste), methanol from natural gas (NG-MeOH), renewable methanol (renewable $\mathrm{MeOH}$, from willow), hydrogen for fuel cells produced from natural gas (NG- $\left.\mathrm{H}_{2}\right)$ or electrolysis based on renewable electricity (elec- $\left.\mathrm{H}_{2}\right)$, hydrotreated vegetable oil ( $\mathrm{HVO}$, from tall oil), and ammonia for both fuels cells and ICEs produced from natural gas $\left(\mathrm{NG}-\mathrm{NH}_{3}\right)$ or electrolysis based on renewable electricity (elec- $\mathrm{NH}_{3}$ ) - are included. The other fuels are assumed used in ICEs.

The 11 fuel options are ranked by ten different performance criteria that influence the choice of marine fuel and their relative importance based on stakeholder preferences. The performance criteria include economic, environmental, technical, and social aspects. The following criteria are included, and described in Table 3: (i) investment cost for propulsion; (ii) operational cost; (iii) fuel price; (iv) available infrastructure; (v) reliable supply of fuel; (vi) acidification; (vii) health impact; (viii) climate change; (ix) safety; and (x) upcoming legislation. The time perspective of the MCDA is 2030 and the focus is on deep sea shipping. The specific criteria were selected through a survey for Swedish maritime stakeholders $[9,48]$. 
Table 3. Description of the criteria included in the multi-criteria decision analysis (MCDA).

\begin{tabular}{|c|c|c|}
\hline & Criterion & Description \\
\hline \multirow{3}{*}{ Economic } & $\begin{array}{l}\text { Investment cost for } \\
\text { propulsion }\end{array}$ & $\begin{array}{l}\text { Defined as capital cost of propulsion and associated } \\
\text { on-board infrastructure per installed engine capacity } \\
\text { in terms of power output and includes cost of } \\
\text { engines, fuel tanks, pipelines, etc., on-board. }\end{array}$ \\
\hline & Operational cost & $\begin{array}{l}\text { Includes crew related cost and maintenance } \\
\text { insurance cost. }\end{array}$ \\
\hline & Fuel cost & $\begin{array}{l}\text { Defined as the estimated relative cost differences of } \\
\text { the fuels based on estimates of production costs, } \\
\text { raw-material prices, and production efficiencies but } \\
\text { the efficiency of the propulsion is also considered. }\end{array}$ \\
\hline \multirow[t]{2}{*}{ Technical } & Available infrastructure & $\begin{array}{l}\text { Defined as compatibility with current infrastructure } \\
\text { including storage, distribution, and bunkering } \\
\text { facilities as well as maturity level of the propulsion } \\
\text { technology. }\end{array}$ \\
\hline & Reliable supply of fuel & $\begin{array}{l}\text { Includes availability of raw material, existing } \\
\text { production and use, and energy security. }\end{array}$ \\
\hline \multirow{3}{*}{ Environmental } & Acidification & $\begin{array}{l}\text { Acidification potential due to } \mathrm{NOx} \text { and } \mathrm{SO}_{2} \\
\text { emissions from fuel combustion. }\end{array}$ \\
\hline & Health impact & $\begin{array}{l}\text { Defined as particulate matter (PM) formation } \\
\text { potential from combustion (in terms of } \mathrm{PM}_{2.5} \text {-equiv.). }\end{array}$ \\
\hline & Climate change & $\begin{array}{l}\text { Global warming potential (GWP100) for emissions of } \\
\mathrm{CO}_{2} \text {, methane }\left(\mathrm{CH}_{4}\right) \text {, and nitrous oxide }\left(\mathrm{N}_{2} \mathrm{O}\right) \text { in } \\
\text { lifecycle perspective. }\end{array}$ \\
\hline \multirow[t]{2}{*}{ Social } & Safety & $\begin{array}{l}\text { Includes risk of fire, explosion, and health hazards } \\
\text { related to fuel handling, considering fuel properties } \\
\text { such as toxicity. }\end{array}$ \\
\hline & Upcoming legislation & $\begin{array}{l}\text { Defined as the likelihood for meeting known and } \\
\text { future emission regulations. }\end{array}$ \\
\hline
\end{tabular}

\subsubsection{Comparison of Marine Fuel Performance}

The characteristics of the included marine fuels are mapped through a literature review. The information used to represent the various criteria for the ammonia pathways are presented in Table 4. Data for LNG are included for comparison. For assumptions related to the non-ammonia fuel options, the reader is referred to Hansson et al. [9] and, for underlying assumptions linked to ships, see Table 1.

For four criteria (available infrastructure, reliable supply of fuel, safety, and upcoming legislation) that are difficult to represent by a single quantitative parameter, a four-level scale (1-4, representing poor, moderate, fairly good, and good) is used for grading underlying aspects (see Table 5) and the average of this grading represent the criteria. The grading for the aspect available infrastructure is based on a judgement from a panel of experts, provided specifically for this study including shipowners, an ammonia producer, a fuel producer and supplier, and marine fuel experts. In the MCDA assessment as well, the other criteria are converted to the range 1-4, where 1 represents the lowest value and 4 the highest, while the remaining parameter values are expressed as their relative value since the relative relation between the options represents a central feature of the assessment. The marine fuel options are then compared and scored, based on their relative estimated performance. 
Table 4. Marine fuel performance for the included ammonia fuel options produced from natural gas $\left(\mathrm{NG}-\mathrm{NH}_{3}\right)$ or electrolysis based on renewable electricity (elec-NH$)$ and for use in fuels cells (FC) and internal combustion engines (ICE) and liquefied natural gas (LNG).

\begin{tabular}{|c|c|c|c|c|c|}
\hline & NG-NH 3 FC & Elec-NH ${ }_{3} \mathrm{FC}$ & NG-NH ${ }_{3}$ ICE & Elec-NH $_{3}$ ICE & LNG \\
\hline $\begin{array}{l}\text { Capital cost for the } \\
\text { propulsion system } \\
\text { (USD } 2015 / \mathrm{kW})\end{array}$ & $5300-11,400^{1}$ & $5300-11,400^{1}$ & $5200-7710^{1}$ & $5200-7710^{1}$ & $\begin{array}{c}5100-7710 \\
{[6,42]}\end{array}$ \\
\hline $\begin{array}{l}\text { Operational cost } \\
\left.\text { (USD }{ }_{2015} / \mathrm{MWh}\right)\end{array}$ & $11^{2}$ & $11^{2}$ & $9^{2}$ & $9^{2}$ & 9 [49] \\
\hline $\begin{array}{l}\text { Indicative fuel cost in } 2030 \\
\left(\mathrm{USD}_{2015} / \mathrm{GJ}\right)^{3}\end{array}$ & $27[6,39,50-53]$ & $35[54]$ & $27[6,50,51]$ & $35[54]$ & $7[6,50,51]$ \\
\hline Available infrastructure ${ }^{4}$ & 1.5 & 1.5 & 1.5 & 1.5 & 2.4 \\
\hline Reliable supply of fuel ${ }^{4}$ & 2.2 & 2.8 & 2.2 & 2.8 & 2.6 \\
\hline $\begin{array}{l}\text { Acidification potential (mole } \\
\text { H+ equiv./MJ fuel) }{ }^{5}\end{array}$ & $0^{6}$ & $0^{6}$ & $2 \times 10^{-47}$ & $2 \times 10^{-47}$ & $\begin{array}{l}8 \times 10^{-5} \\
{[55-57]}\end{array}$ \\
\hline $\begin{array}{c}\text { Health impact as } \mathrm{PM}_{2.5} \\
\text { equivalents }(\mathrm{mg} / \mathrm{MJ})^{8}\end{array}$ & 0 & 0 & $3.4^{9}$ & $3.4^{9}$ & $1.4[55-57]$ \\
\hline $\begin{array}{c}\text { Climate change entire } \\
\text { lifecycle, GWP100 (g } \\
\mathrm{CO}_{2} \text {-equiv /MJ) }\end{array}$ & 140 & 30 & 140 & 30 & $80[56-59]$ \\
\hline Safety ${ }^{4}$ & $2.3^{11}$ & $2.3^{11}$ & $2.3^{11}$ & $2.3^{11}$ & $2.5^{11}$ \\
\hline Upcoming legislation ${ }^{4}$ & $3.6^{12}$ & $3.9^{12}$ & $3.0^{12}$ & $3.3^{12}$ & $2.9^{12}$ \\
\hline
\end{tabular}

${ }^{1}$ SCR technology is assumed applied for the ICE alternatives (at $133 \mathrm{USD} / \mathrm{kW}$ ), assumed ICE engine price $600 \mathrm{USD} / \mathrm{kW}$ and SOFC price 925-1315 USD/kW [44]. Storage cost is assumed to be in the range from half of the LNG storage cost to the same as the LNG storage cost estimated at 35-70 USD/GJ [6]. ${ }^{2}$ Assumed to have slightly higher operational cost than LNG, but lower than $\mathrm{H}_{2}$ [6]. ${ }^{3}$ It is difficult to predict fuel prices in 2030. Our estimate is therefore based on available data on fuel production cost, historical prices, and rough estimates based on raw material prices and conversion efficiencies. ${ }^{4}$ A four-level scale (1-4, representing Poor, moderate, fairly good, and good) is used for grading underlying aspects for these parameters and the average value represent the criteria. For some aspects this is partly based on judgement from a panel of experts. Available infrastructure is for input on current loading infrastructure of ammonia in ports based on [24]. ${ }^{5}$ Acidification potential is based on $\mathrm{NOx}$ and $\mathrm{SO}_{2}$ emissions from combustion using characterization factors for acidification potential based accumulated exceedance methods for $\mathrm{NOx}$ and $\mathrm{SO}_{2}$ resulting in 0.74 and $1.31 \mathrm{~mol}$ of charge (mole) per kg substance emitted respectively [60,61]. ${ }^{6}$ For ammonia used in fuel cells, there is a risk of nitrogen oxides $\left(\mathrm{NO}_{\mathrm{X}}\right)$ and $\mathrm{N}_{2} \mathrm{O}$ emission but, due to the lack of quantitative data, zero emission is used here. There is also a risk of ammonia emissions for all ammonia pathways potentially influencing acidification but due to lack of data that has not been considered in this study. ${ }^{7}$ Assumed to have the same level of acidifying emissions as LNG. ${ }^{8}$ Human health impact is based on emissions of $\mathrm{PM}_{10}, \mathrm{SO}_{2}$, and $\mathrm{NO}_{\mathrm{X}}$ from combustion and represented by mass $\mathrm{PM}_{2.5}$-equivalents. Characterization factors for $\mathrm{PM}_{10}, \mathrm{SO}_{2}$, and $\mathrm{NO}_{\mathrm{X}}$ are $0.2278,0.0611$, and 0.0072 , respectively [61]. ${ }^{9}$ Assumed to be associated with the same level of $\mathrm{PM}_{2.5}$ equivalents emissions as MeOH ICE [9]. ${ }^{10}$ Estimated based on emission data by Bicer and Dincer [62], Kramer et al. [63], and Wood [64]. ${ }^{11}$ Based on safety data in various ammonia safety sheets and Zamfirescu and Dincer [65]. 12 Based on Ash [24], Bartels [66], and Reiter and Kong [67].

Table 5. Expert evaluation of the underlying aspects of the criteria "available infrastructure", "reliable supply of fuel", "safety" and "upcoming legislation". The scale 1-4 (poor, moderate, fairly well, and good) is applied and for the underlying aspects linked to "available infrastructure" the average evaluation is presented with range given in parenthesis.

\begin{tabular}{|c|c|c|c|c|}
\hline & NG-NH ${ }_{3}$ FC & Elec-NH 3 FC & NG-NH 3 ICE & Elec-NH $\mathrm{NH}_{3} \mathrm{ICE}$ \\
\hline \multicolumn{5}{|l|}{ Available infrastructure } \\
\hline $\begin{array}{l}\overline{\text { Compatibility to existing }} \\
\text { infrastructure }\end{array}$ & $1.86(1-3)$ & $1.86(1-3)$ & $1.86(1-3)$ & $1.86(1-3)$ \\
\hline Adaptability to existing ships & $1.57(1-2)$ & $1.57(1-2)$ & $1.57(1-2)$ & $1.57(1-2)$ \\
\hline Engine technology maturity & $1.71(1-3)$ & $1.71(1-3)$ & $1.71(1-3)$ & $1.71(1-3)$ \\
\hline $\begin{array}{l}\text { Current amount of storage and } \\
\text { bunkering capability }\end{array}$ & 1 & 1 & 1 & 3 \\
\hline \multicolumn{5}{|l|}{ Reliable supply of fuel } \\
\hline$\overline{\text { Raw material availability }}$ & 3 & 4 & 3 & 4 \\
\hline Current production & 4 & 1 & 4 & 1 \\
\hline Current use as marine fuel & 1 & 1 & 1 & 1 \\
\hline $\begin{array}{l}\text { Energy security 1: Global supply } \\
\text { potential distribution }\end{array}$ & 1 & 4 & 1 & 4 \\
\hline $\begin{array}{c}\text { Energy security 2: Political } \\
\text { stability }\end{array}$ & 2 & 4 & 2 & 4 \\
\hline
\end{tabular}


Table 5. Cont.

\begin{tabular}{|c|c|c|c|c|}
\hline & $\mathrm{NG}-\mathrm{NH}_{3} \mathrm{FC}$ & Elec-NH $_{3}$ FC & 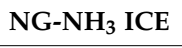 & Elec-NH ${ }_{3}$ ICE \\
\hline \multicolumn{5}{|l|}{ Safety } \\
\hline Risk of explosion or fire & 3 & 3 & 3 & 3 \\
\hline Toxicity & 1 & 1 & 1 & 1 \\
\hline Health hazards & 1 & 1 & 1 & 1 \\
\hline In terms of cryogenic liquid & 4 & 4 & 4 & 4 \\
\hline \multicolumn{5}{|l|}{ Upcoming legislation } \\
\hline Sulphur dioxide $\left(\mathrm{SO}_{2}\right)$ global 2020 & 4 & 4 & 4 & 4 \\
\hline $\mathrm{NO}_{X}$ Tier III & 4 & 4 & 2 & 2 \\
\hline $\begin{array}{c}\text { IMO } 2050 \text { GHG target (exhaust } \\
\text { emissions) }\end{array}$ & 4 & 4 & 4 & 4 \\
\hline $\begin{array}{l}\text { IMO } 2100 \text { GHG targets (life cycle } \\
\text { perspective) }\end{array}$ & 1 & 4 & 1 & 4 \\
\hline Particle mass & 4 & 4 & 3 & 3 \\
\hline Particle numbers & 4 & 4 & 2 & 2 \\
\hline Methane emissions & 4 & 4 & 4 & 4 \\
\hline Ammonia emissions & 3 & 3 & 3 & 3 \\
\hline Scrubber ban & 4 & 4 & 4 & 4 \\
\hline
\end{tabular}

\subsubsection{Weighting of Criteria}

The weights of the different criteria applied in this study are based on Hansson et al. [9] and Månsson [48]. These weights were settled during a workshop with a group of shipping related stakeholders. The stakeholders included ship-owners, engine manufacturers, fuel producers, Swedish government authority representatives, and relevant researchers.

Weightings were produced individually and in groups representing the preferences of: (i) ship-owners; (ii) fuel producers; (iii) engine manufacturers; and (iv) Swedish government authorities. The base case, representing the "combined view" of the stakeholders is based on the weighted geometric mean of all stakeholders individually produced pairwise comparison matrices for the included criteria showing their individual preferences.

In terms of outcome for the relative importance of the overall criteria, the economic criteria are the most important, followed by social and environmental criteria for the combined group. Ship-owners, fuel producers, and engine manufacturers also value economic criteria the highest, but followed by social and technical aspects for ship-owners while technical and social for the other groups. On the other hand, government authorities value environmental and social aspects most, followed by economic criteria.

In terms of outcome for the relative importance of each criterion, fuel cost is, as expected, the most important economic criterion (followed by investment cost), and reliable supply the most important technical criterion, for all stakeholder groups. As environmental criterion climate change is considered the most important, except for engine manufacturers that give health impact higher weight. In terms of social criterion, upcoming legislation is the most important except for ship-owners that value safety most.

As the final step of the MCDA, the included fuel options are ranked based on the scoring of alternatives and the criteria weighting, i.e., by combining the pairwise comparison matrices (linear combination of normalized priority vectors) produced following the AHP approach. For more details on the method, see Appendix A. The influence of different criteria weights on the final fuel ranking (outcome of the MCDA) is assessed with the weightings of the different stakeholder groups. This represents the sensitivity analysis of the MCDA assessment.

\section{Results}

\subsection{Cost-effective Future Marine Fuel Options}

In the beginning of the studied time period, the use of MGO and LNG in ICEs dominates the fuel use in the shipping sector. In the 450-ppm scenario, the use of MGO starts to decrease from 2020 and 
is almost phased out by 2100. The use of LNG in ICEs increases but peaks around 2040; thereafter, it decreases and instead LNG in FCs are introduced to some extent. Further, from 2050, the use of hydrogen in FCs increases substantially replacing the major share of all other fuels. The development until 2040 is similar in the 550-ppm scenario. However, in this scenario, LNG in FCs becomes the dominating fuel, replacing most of the MGO and LNG in ICEs while $\mathrm{H}_{2}$ in FCs is found cost-effective first from around 2080. The cost-effective fuel options for shipping in 2050 and 2070 for the two climate scenarios in energy terms are presented in Figure 1. The share of different fuel options of the total fuel use for shipping in 2050 and 2070 for the two climate scenarios are also presented in Figure 1.

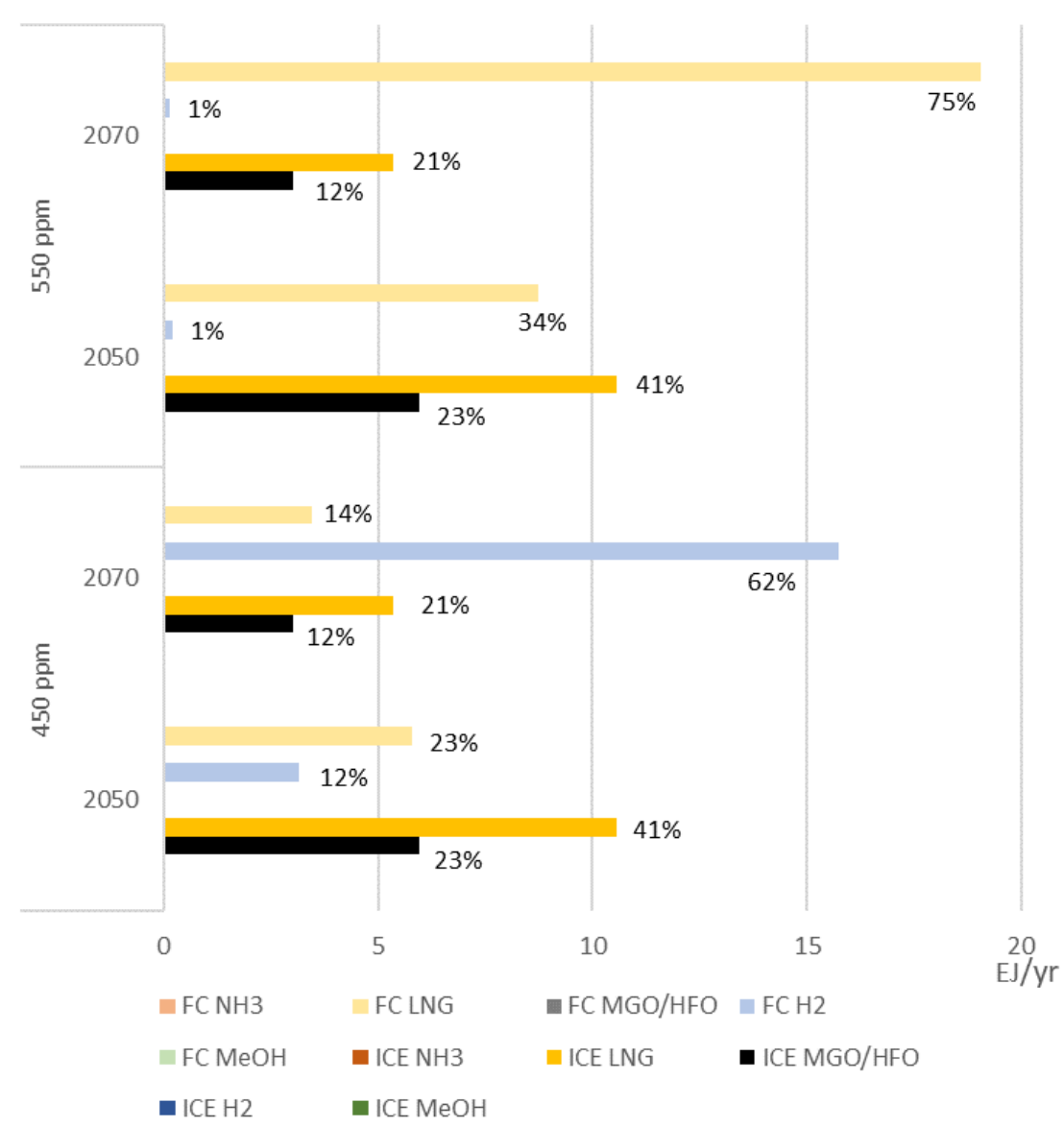

Figure 1. Fuel volumes (in EJ/year) for different fuel/powertrain combinations in cost-effective fuel choices for shipping in 2050 and 2070 for the two climate scenarios 450 and $550 \mathrm{ppm}$. The share of different fuel options of the total fuel use for shipping (in percentage) in the four cases are presented at the end of each bar. FC, fuel cells; ICE, internal combustion engine; MGO/HFO, conventional fossil oil; $\mathrm{LNG}$, liquefied natural gas; $\mathrm{NH}_{3}$, ammonia; $\mathrm{H}_{2}$, hydrogen; $\mathrm{MeOH}$, biofuels, fossil $\mathrm{MeOH}$, and electro-methanol.

To summarize, the energy systems modeled indicate that in climate scenarios the use of oil-based marine fuels decreases as expected and in the short-term natural gas-based fuels in the form of LNG represent cost-effective fuel choices. However, in the long-term and in the case of more stringent climate targets, the use of hydrogen represents the most cost-effective option for the shipping sector, thus being more cost-effective than ammonia. The reason is that, although ammonia has significantly lower storage costs on container ships, this does, in our model setup, not outweigh the additional cost of converting hydrogen to ammonia in a system perspective. For example, in terms of electricity demand, in the case of renewable ammonia produced from electricity, it is estimated that an electricity input of 3-4 times the actual work propelling the ship is needed. 
Biofuels and methanol pathways do not turn out to be cost-effective fuel options in the shipping sector either. The reason is that the biomass is used for other energy sectors, which with the given model set up is found more cost-effective.

The Monte-Carlo analyses performed on efficiency and investment cost of ammonia production as well as ship costs also confirm that this finding does not seem to be sensitive to key parameter values since only very marginal amounts of ammonia are introduced in these runs. Thus, using hydrogen in the case of stringent climate targets turns out to be more cost effective in all cases.

\subsection{Ranking of Marine Fuels Based on the MCDA Assessment}

The relative performances of the included marine fuels for the different criteria is presented in Figure 2. A high value represents a better performance, e.g., lower cost, lower emissions, higher level of reliable supply of fuel, etc. None of the investigated options performs best for all criteria. Ammonia produced from renewable electricity and used in fuel cells has comparable performance to hydrogen produced from renewable electricity used in fuel cells. Ammonia used in ICEs has worse performance related to acidification and health impacts and ammonia produced from natural gas has worse performance connected to climate change.
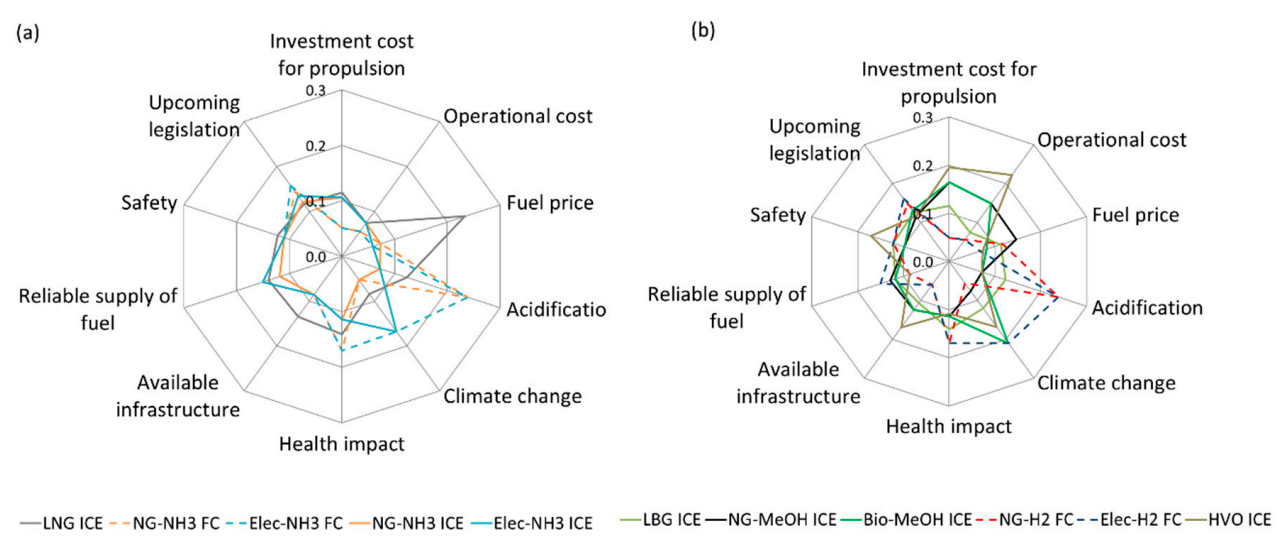

Figure 2. Relative marine fuel performance for each criterion: (a) the ammonia fuel options and LNG; and (b) the remaining fuel options. Higher values represent better performance.

The rankings of the studied marine fuels for the combined stakeholder group and for the different stakeholder subgroups are presented in Figure 3 and the ranking order for the ammonia options is in Table 6 . The presented ranking is valid for the assumptions linked to criteria and performance made in this study.

For the combined stakeholder case, LNG is ranked highest with hydrotreated vegetable oil (HVO ICE) second, and then renewable hydrogen in fuel cells (Elec- $\mathrm{H}_{2} \mathrm{FC}$ ). Renewable ammonia in fuel cells (Elec- $\mathrm{NH}_{3} \mathrm{FC}$ ) and in internal combustion engines (Elec-NH $\mathrm{NH}_{3} \mathrm{ICE}$ ) are ranked fifth and eighth, respectively, while natural gas-based ammonia ends up in the bottom of the ranking. For ship-owners, fuel producers, and engine manufacturers, LNG is ranked highest followed by natural gas-based methanol (NG-MeOH ICE). The ammonia options end up in the bottom or lower part of the ranking for all these stakeholder groups (seventh or lower) and there are only minor differences between the other included fuel options. The main reason behind the similar ranking for these stakeholder groups is their relatively high weight on economy and particularly fuel cost and similar weighting overall. The views of governmental authorities result in Elec- $\mathrm{H}_{2} \mathrm{FC}$ being ranked highest followed by Elec- $\mathrm{NH}_{3}$ FC, but here biomass-based methanol (Bio-MeOH ICE) is in third place, HVO ICE in fourth place, and Elec- $\mathrm{NH}_{3}$ ICE in fifth place. The reason for this is that these stakeholders consider GHG emissions and the potential to meet regulations as the top criteria. The natural gas-based ammonia options are in the bottom of the ranking for governmental authorities. 


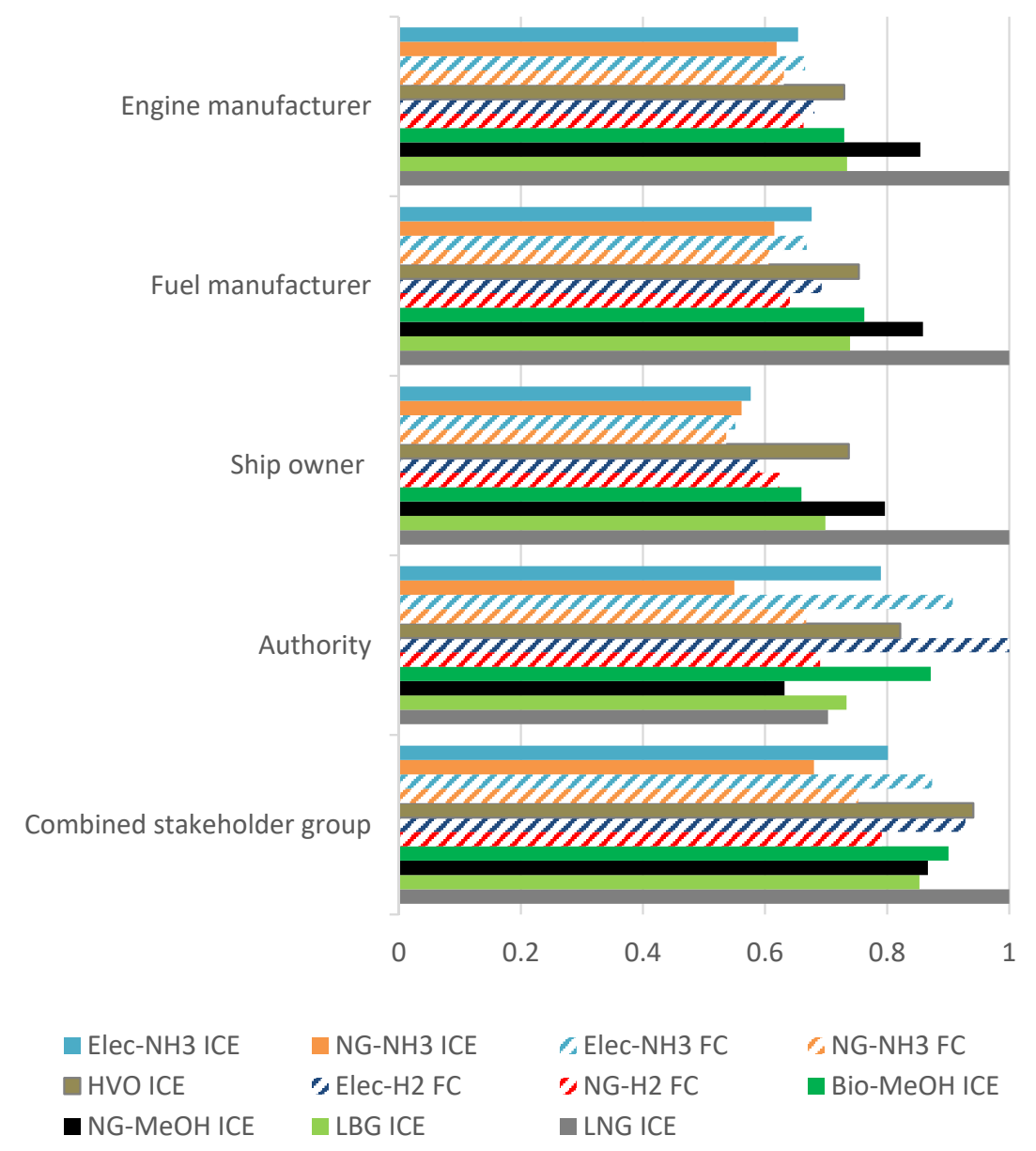

Figure 3. Ranking of the studied marine fuels for the combined stakeholder group and for the different stakeholder groups. The value " 1 " is assigned to the fuel ranked the highest and the values for the other fuel are expressed relative to the fuel ranked the highest.

Table 6. Ranking order of the ammonia fuel options (from 1 to 11, where 1 indicates highest ranking) in the different stakeholder groups.

\begin{tabular}{|c|c|c|c|c|c|}
\hline Fuels & $\begin{array}{l}\text { Combined } \\
\text { Group }\end{array}$ & $\begin{array}{l}\text { Gov. } \\
\text { Authorities }\end{array}$ & Ship-Owner & $\begin{array}{c}\text { Fuel } \\
\text { Producer }\end{array}$ & $\begin{array}{c}\text { Engine } \\
\text { Manufacturer }\end{array}$ \\
\hline $\mathrm{NG}-\mathrm{NH}_{3} \mathrm{FC}$ & 10 & 9 & 11 & 11 & 10 \\
\hline Elec-NH${ }_{3} \mathrm{FC}$ & 5 & 2 & 10 & 8 & 7 \\
\hline $\mathrm{NG}-\mathrm{NH}_{3} \mathrm{ICE}$ & 11 & 11 & 9 & 10 & 11 \\
\hline Elec-NH $\mathrm{NH}_{3} \mathrm{ICE}$ & 8 & 5 & 8 & 7 & 9 \\
\hline
\end{tabular}

\section{Discussion}

To support a demand for ammonia as fuel in shipping, the production of renewable ammonia needs to increase substantially. As ammonia is currently mainly used for fertilizer production, this might lead to competition with potentially higher ammonia prices and higher food prices at least in the short-term. However, compared to biofuels, large-scale production of renewable based electricity needed for renewable ammonia production does not have the same physical restrictions.

Currently, the price related to energy content of ammonia is substantially higher than for MGO and LNG. However, when comparing future cost estimates of alternative marine fuels, the price for ammonia is expected to be in almost the same range as hydrogen.

Regarding performance of ammonia as a fuel, there are remaining issues with ignition, specific fuel consumption, materials, and emissions linked to ammonia as marine fuel. Emissions from the use 
of ammonia as fuel can possibly be dealt with and the engines can be improved. However, before ammonia can be used on ships further demonstrations of emissions and efficiencies are called for. There are also remaining issues linked to safety that is a major concern when considering ammonia as a fuel. Firm rules for design of ammonia systems and for the handling of such systems are needed in order to avoid negative impacts. It remains to conclude if safety issues will represent a key obstacle for ammonia as marine fuel.

Although ammonia is not considered to be the most cost-effective option in the GET model in this study, ammonia may still be of interest for marine applications, as indicated by the MCDA. For example, the current version of the GET model does not consider the possibility to produce ammonia directly from hydrogen without compression or liquefaction. Including this might influence the result for ammonia. In addition, it is possible that the shipping sector in the future will not be dominated by only one alternative fuel but a combination of fuels. The introduction of dual-fuel engines supports this, and this might improve the prerequisites for ammonia as marine fuel. There might also be situations where ammonia becomes a cost-effective option also in future energy scenarios developed with cost-minimization. For example, if hydrogen liquefaction, storage, distribution, and use in fuel cells turns out to be more expensive than expected while the ammonia production process improves, the use in ICEs ammonia might be more attractive.

In addition, unexpected development for other options in the shipping as well as other sectors might also influence the outcome since the development in other sectors influences the cost-effective fuel choices in the shipping sector. Future cost estimates are always uncertain and assuming a higher cost for individual parts of the chain might also change the cost-effectiveness of ammonia vs. hydrogen. The sensitivity analysis performed tests uncertainties linked to some of the parameter values. However, more sensitivity assessments might yield more insights. For example, costs linked to liquefaction of hydrogen (which is needed for use in ships) and cost for converters should be studied more. It should also be remembered that the GET model is not used to predict the future but to understand how future fuel choices are influenced by different assumptions.

The modeling and scenario development by ben Brahim et al. [22] indicate that changes in costs for a specific fuel technology influences the outcome to a large extent; for example, in the case of a $20 \%$ reduction in costs for ammonia or methanol, they would take over the role of hydrogen as the main renewable fuel in their scenarios. However, in our energy systems modeling, the prospects for ammonia is not found sensitive to changes in costs to the same extent with the given set up and sensitivity assessments made. The reason might be the different system boundaries, the focus on Danish shipping in the study by ben Brahim et al. [22] vs. the total global energy system in this study or different assumptions regarding fuel cost relations and how linked they are.

The ranking of the included alternative marine fuel options varies depending on the preferences among stakeholder groups. The ranking in this study is only valid for the included criteria, i.e., extending with additional criteria may change the ranking. The key insight from the MCDA assessment is that ammonia is only ranked high for governmental authorities and to some extent for the total stakeholder group and then primarily renewable ammonia in fuel cells. It is also important to note that the ranking is very sensitive to assumption about the fuel prices in 2030; a change in the relative fuel prices has the potential to change the overall ranking in the MCDA.

From an overall perspective in the MCDA, using ammonia in fuel cells seems to perform better than ammonia in internal combustion engines. This is partly due to the higher efficiency of the fuel cells but also due to better performance in terms of health impact and acidification, and it is therefore somewhat more likely that the fuel cell pathway will meet upcoming legislation However, ship owners and fuel producers rank ammonia in ICEs somewhat higher than corresponding FC options. Thus, this relation should be further assessed as more certainty in cost, performance, etc. becomes available.

Further sensitivity assessment of the parameter values judged most uncertain would also be valuable (i.e., to change the scoring of selected criteria). For example, estimating the fuel price in 2030 
is very difficult. It would be interesting to further test the influence on the fuel ranking in the MCDA of changes in the fuel prices.

The fuel ranking is also influenced by the selection of criteria. Adding more criteria may change the outcome to some extent. The impact in terms of fuel ranking will depend on the performance and weight of the new criteria in comparison to the already included criteria and is not possible to predict. However, the criteria included in this study cover several key aspects, and it is not clear that a larger number of criteria will clarify the role of ammonia. However, it would be interesting to specifically study the effect on cargo capacity, more issues related to the toxicity of ammonia, and the impact of current investments. Thus, the criteria included in the MCDA cover a limited number of all sustainability aspects related to marine fuels and the study should not be seen as a complete sustainability assessment.

Ammonia from natural gas with CCS is another option with potentially low climate impact and could be further assessed in future studies. Policy makers need to consider that some ammonia routes are more beneficial than others and make sure that policy and regulations promote these pathways.

To conclude, in the long-term and to reach global GHG reduction, the energy systems modeled in this paper indicate that the use of hydrogen represents a more cost-effective option for the shipping sector than ammonia. However, in the MCDA covering more aspects but with a shorter time perspective, we find that ammonia may be almost as interesting for shipping related stakeholders as hydrogen and various biomass-based fuels. Due to primarily the potential low climate impact, ammonia has potential as a future marine fuel, but many issues remain to be solved before it can be introduced in large-scale, and more detailed additional assessments and comparisons are needed. The following future research areas are suggested:

- In-depth assessments of ammonia as marine fuel from a system perspective comparing ammonia with other potential marine fuel options and considering technical and economic feasibility, safety, and environmental performance are needed.

- Feasibility studies could assess the possibility of introducing ammonia as a marine fuel covering assessments of fuel systems, bunkering, safety routines, etc.

- Demonstration projects could convert marine engines to use ammonia as fuel.

- Demonstration projects could test fuels cells in combination with ammonia to show a business case regarding costs and durability.

- Additional assessments with an energy-system perspective with more detailed representation of the shipping and aviation sector will increase understanding about under which circumstances different renewable marine fuels are cost-effective and interesting for different parts of the shipping sector.

A large-scale introduction of alternative marine fuels, ammonia as well as others, needs to be supported by policy measures. The choice and design of these policies will also influence the prerequisites for different marine fuels. Thus, policy analysis clarifying the impact of different policies and policy designs on different marine fuel options are also needed.

Author Contributions: Conceptualization and overall methodology, J.H. and S.B.; literature review of ammonia and data collection, J.H., S.B., and E.F.; energy system modeling, M.L. and S.B.; multi-criteria assessment, J.H. and S.B.; analysis and investigation, J.H., S.B., E.F., and M.L.; writing-original draft preparation, J.H., S.B., E.F., and M.L.; writing-review and editing, J.H., S.B., E.F., and M.L.; visualization, J.H., S.B., and M.L.; project administration, J.H.; and funding acquisition, J.H., S.B., and E.F. All authors have read and agreed to the published version of the manuscript.

Funding: This research was funded by the Swedish Energy Agency, grant number 47479-1 Pathways towards $50 \%$ reduction of GHGs from shipping until 2050 and the Swedish Transport Administration's industry program Sustainable shipping led by the Swedish Maritime Competence Centre (Lighthouse), grant number FS2_2019 The potential of ammonia as fuel for shipping and FP2_E_2020 Assessment of hydrogen, ammonia and battery-electric propulsion for future zero carbon shipping.

Acknowledgments: We gratefully acknowledge Josefin Lövdahl and Maria Magnusson for the initial assessment performed in their Master Thesis at Chalmers University of Technology supervised by the authors of this paper. 
Conflicts of Interest: The authors declare no conflict of interest. The funders had no role in the design of the study; in the collection, analyses, or interpretation of data; in the writing of the manuscript, or in the decision to publish the results.

\section{List of Abbreviations}

$\begin{array}{ll}\text { Abbreviation } & \text { Meaning } \\ \mathrm{AHP} & \text { Analytic Hierarchy Process } \\ \mathrm{CCS} & \text { Carbon capture and storage } \\ \mathrm{CH}_{4} & \text { Methane } \\ \mathrm{CI} & \text { Compression ignition } \\ \mathrm{CO}_{2} & \text { Carbon dioxide } \\ \mathrm{Elec}-\mathrm{H}_{2} & \text { Hydrogen from electrolysis based on renewable electricity } \\ \mathrm{Elec}-\mathrm{NH}_{3} & \text { Ammonia from electrolysis based on renewable electricity } \\ \mathrm{FC} & \text { Fuel cell } \\ \mathrm{GET} & \text { Global Energy Transition Model } \\ \mathrm{GHG} & \text { Greenhouse gas } \\ \mathrm{GWP} 100 & \text { Global warming potential over 100-year time horizon } \\ \mathrm{H}_{2} & \text { Hydrogen } \\ \mathrm{HB} & \text { Haber-Bosch } \\ \mathrm{HFO} & \text { Heavy fuel oil } \\ \mathrm{HVO} & \text { Hydrotreated vegetable oil } \\ \mathrm{ICE} & \text { Internal combustion engine } \\ \mathrm{IMO} & \text { International Maritime Organization } \\ \mathrm{LBG} & \text { Liquefied biogas } \\ \mathrm{LNG} & \text { Liquefied natural gas } \\ \mathrm{MCDA} & \text { Multi-criteria decision analysis } \\ \mathrm{MeOH} & \text { Methanol } \\ \mathrm{MGO} & \text { Marine gas oil } \\ \mathrm{NG} & \text { Natural gas } \\ \mathrm{NG-H} & \text { Selective Catalytic Reduction } \\ \mathrm{NG-MeOH} & \text { Hydrogen from natural gas } \\ \mathrm{NG-NH} & \text { Methanol from natural gas } \\ \mathrm{NH} & \text { Ammonia from natural gas } \\ \mathrm{N}_{2} \mathrm{O} & \text { Ammonia } \\ \mathrm{NO} & \text { Nitrous oxide } \\ \mathrm{PEM} \mathrm{FC} & \text { Nitrogen oxides } \\ \mathrm{PM} & \text { Proton-exchange membrane fuel cell } \\ \mathrm{SCR} & \text { Particulate matter } \\ \mathrm{SI} & \text { SOFC } \\ \mathrm{USD} & \end{array}$

\section{Appendix A. Pairwise Comparisons in the Analytic Hierarchy Process (AHP)}

The pairwise comparison matrices for the included criteria applied in this study are expressed in mathematical terms by Equation (A1) where $a_{i j}>0$ expresses the degree of preference of aspect $x_{i}$ to $x_{j}$ using the fundamental scale of absolute numbers for intensities defined by Saaty in AHP (Table A1).

$$
P C M=\left(a_{i j}\right)_{n \times n} \quad P C M=\left(\begin{array}{cccc}
a_{11} & a_{12} & \cdots & a_{1 n} \\
a_{21} & a_{22} & \cdots & a_{2 n} \\
\vdots & \vdots & \ddots & \vdots \\
a_{n 1} & a_{n 2} & \cdots & a_{n n}
\end{array}\right)
$$


Table A1. Fundamental scale of absolute numbers used in pairwise comparisons of alternatives and criteria defined by Saaty in AHP [47].

\begin{tabular}{ccc}
\hline Intensity of Importance. & Definition & Explanation \\
\hline $\mathbf{1}$ & Equal importance & $\begin{array}{c}\text { Two elements contribute equally } \\
\text { to the objective }\end{array}$ \\
$\mathbf{3}$ & Soderate importance & $\begin{array}{c}\text { Experience or judgment slightly } \\
\text { favors one element over another } \\
\text { Experience or judgment strongly } \\
\text { favors one element over another } \\
\text { One element is favored very } \\
\text { strongly over another }\end{array}$ \\
$\mathbf{7}$ & Very strong importance & $\begin{array}{c}\text { The evidence favoring one } \\
\text { element over another is the } \\
\text { highest possible }\end{array}$ \\
\hline
\end{tabular}

A consistency check of the comparisons in the matrices is done by solving the characteristic equation (Equation (A2)). The maximum eigenvalue, $\lambda \_$max, is used for calculating a consistency index (CI), Equation (A3), and thereafter a consistency ratio (CR), Equation (A4), where $\mathrm{n}$ is the size of the pairwise comparison matrix and $\mathrm{RI}_{\mathrm{n}}$ a random index.

$$
\begin{gathered}
\operatorname{det}(\mathrm{PCM}-\lambda \cdot \mathrm{I})=0 \\
\mathrm{CI}(\mathrm{PCM})=\frac{\lambda_{\max }-\mathrm{n}}{\mathrm{n}-1} \\
\mathrm{CR}(\mathrm{PCM})=\frac{\mathrm{CI}(\mathrm{PCM})}{\mathrm{RI}_{\mathrm{n}}}
\end{gathered}
$$

The normalized priority vector is for each matrix calculated as the geometric mean divided by the sum of the priorities. Based on the individual stakeholder pairwise comparison matrices, group priority vectors are constructed by aggregation of individual priorities assuming equal importance and using the weighted geometric mean. The normalized priority (i.e., relative importance) for each criterion is presented in Table A2. The final ranking of the alternative marine fuels is then derived by linear combination of the group priority vectors and the normalized priority vector from the pairwise comparison.

Table A2. Relative importance of the criteria expressed as normalized priorities (rounded figures) based on the pairwise comparisons of the criteria performed by the stakeholders individually and for the stakeholder groups.

\begin{tabular}{cccccc}
\hline Criteria & $\begin{array}{c}\text { Combined } \\
\text { Case }\end{array}$ & Authorities & Ship-Owners & $\begin{array}{c}\text { Fuel } \\
\text { Producers }\end{array}$ & $\begin{array}{c}\text { Engine } \\
\text { Manufacturers }\end{array}$ \\
\hline Investment cost & 0.26 & 0.25 & 0.20 & 0.23 & 0.23 \\
Operational cost & 0.16 & 0.25 & 0.07 & 0.12 & 0.12 \\
Fuel cost & 0.58 & 0.50 & 0.73 & 0.65 & 0.65 \\
Available infrastructure & 0.29 & 0.17 & 0.20 & 0.20 & 0.20 \\
Reliable supply of fuel & 0.71 & 0.83 & 0.80 & 0.80 & 0.80 \\
Acidification & 0.21 & 0.19 & 0.10 & 0.11 & 0.26 \\
Health impact & 0.30 & 0.08 & 0.23 & 0.31 & 0.64 \\
Climate change & 0.50 & 0.73 & 0.67 & 0.58 & 0.11 \\
Safety & 0.48 & 0.25 & 0.80 & 0.17 & 0.17 \\
Upcoming legislation & 0.52 & 0.75 & 0.20 & 0.83 & 0.83 \\
\hline
\end{tabular}

\section{References}

1. IMO. Adoption of the Initial IMO Strategy on Reduction of GHG Emissions from Ships and Existing IMO Activity Related to Reducing GHG Emissions in the Shipping Sector; Note by the International Maritime Organization to the UNFCCC Talanoa Dialogue; International Maritime Organization: London, UK, 2018; pp. 1-27.

2. Balcombe, P.; Brierley, J.; Lewis, C.; Skatvedt, L.; Speirs, J.; Hawkes, A.; Staffell, I. How to decarbonise international shipping: Options for fuels, technologies and policies. Energy Convers. Manag. 2019, 182, 72-88. [CrossRef] 
3. Bouman, E.A.; Lindstad, E.; Rialland, A.I.; Strømman, A.H. State-of-the-art technologies, measures, and potential for reducing GHG emissions from shipping-A review. Transp. Res. Part D Transp. Environ. 2017, 52, 408-421. [CrossRef]

4. ICCT. Reducing Greenhouse Gas Emissions from Ships-Cost Effectiveness of Available Options; White Paper Number 11; International Council on Clean Transportation: Washington DC, WA, USA, 2011.

5. Psaraftis, H.N. Ship routing and scheduling: The cart before the horse conjecture. Marit. Econ. Logist. 2017, 21, 111-124. [CrossRef]

6. Taljegard, M.; Brynolf, S.; Grahn, M.; Andersson, K.; Johnson, H. Cost-Effective Choices of Marine Fuels in a Carbon-Constrained World: Results from a Global Energy Model. Environ. Sci. Technol. 2014, 48, 12986-12993. [CrossRef] [PubMed]

7. Traut, M.; Larkin, A.; Anderson, K.; McGlade, C.; Sharmina, M.; Smith, T. CO2 abatement goals for international shipping. Clim. Policy 2018, 18, 1066-1075. [CrossRef]

8. DNV GL. Comparison of Alternative Marine Fuels; DNV GL AS Maritime: Høvik, Norway, 2019.

9. Hansson, J.; Månsson, S.; Brynolf, S.; Grahn, M. Alternative marine fuels: Prospects based on multi-criteria decision analysis involving Swedish stakeholders. Biomass Bioenergy 2019, 126, 159-173. [CrossRef]

10. Kirstein, L.; Halim, R.; Merk, O. Decarbonising Maritime Transport_Pathways to Zero-Carbon Shipping by 2035; OECD International Transport Forum: Paris, France, 2018.

11. Klüssmann, J.N.; Ekknud, L.R.; Ivarsson, A.; Schramm, J. The Potential for Ammonia as a Transportation Fuel-A Literature Review; The Technical University of Denmark (DTU): Lyngby, Denmark, 2019.

12. Maritime Knowledge Centre, TNO and TU. Framework CO2 Reduction in Shipping; Maritime Knowledge Centre, TNO and TU: Delft, The Netherlands, 2017.

13. CSR Netherlands. Ship 2040: Pioneers of the Maritime Sector; MVO Nederland: Utrecht, the Netherlands, 2017.

14. Lloyd's Register and University Maritime Advisory Services (UMAS). Zero-Emission Vessels 2030. How Do We Get There; Lloyd's Register Group Limited: London, UK, 2017.

15. Ahlgren, S.B.F.; Hulteberg, C. Produktion av Kvävegödsel Baserad på Förnybar Energi-En översikt av Teknik, Miljöeffekter och Ekonomi för Några Alternativ; Sveriges Lantbruksuniversitet: Uppsala, Sweden, 2015.

16. Giddey, S.; Badwal, S.P.S.; Munnings, C.; Dolan, M. Ammonia as a Renewable Energy Transportation Media. ACS Sustain. Chem. Eng. 2017, 5, 10231-10239. [CrossRef]

17. Kang, D.W.; Holbrook, J.H. Use of NH3 fuel to achieve deep greenhouse gas reductions from US transportation. Energy Rep. 2015, 1, 164-168. [CrossRef]

18. Deniz, C.; Zincir, B. Environmental and economical assessment of alternative marine fuels. J. Clean. Prod. 2016, 113, 438-449. [CrossRef]

19. Ren, J.; Liang, H. Measuring the sustainability of marine fuels: A fuzzy group multi-criteria decision making approach. Transp. Res. Part D Transp. Environ. 2017, 54, 12-29. [CrossRef]

20. Ren, J.; Lützen, M. Selection of sustainable alternative energy source for shipping: Multi-criteria decision making under incomplete information. Renew. Sustain. Energy Rev. 2017, 74, 1003-1019. [CrossRef]

21. Halim, R.; Kirstein, L.; Merk, O.; Martinez, L. Decarbonization Pathways for International Maritime Transport: A Model-Based Policy Impact Assessment. Sustainability 2018, 10, 2243. [CrossRef]

22. Ben Brahim, T.; Wiese, F.; Münster, M. Pathways to climate-neutral shipping: A Danish case study. Energy 2019, 188. [CrossRef]

23. Yara. Fertilizer Industry Handbook; Yara: Oslo, Norway, 2018.

24. Ash, N.; Scarbrough, T. Sailing on Solar: Could Green Ammonia Decarbonise International Shipping; Environmental Defense Fund: London, UK, 2019.

25. Soloveichik, G. Electrochemical synthesis of ammonia as a potential alternative to the Haber-Bosch process. Nat. Catal. 2019, 2, 377-380. [CrossRef]

26. Shipman, M.A.; Symes, M.D. Recent progress towards the electrosynthesis of ammonia from sustainable resources. Catal. Today 2017, 286, 57-68. [CrossRef]

27. Brown, T. Green Ammonia: Haldor Topsoe's Solid Oxide Electrolyzer; Ammonia Industry: Brooklyn, NY, USA, 2019; Volume 2020, Available online: https://ammoniaindustry.com/ (accessed on 4 December 2019).

28. Valera-Medina, A.; Xiao, H.; Owen-Jones, M.; David, W.I.F.; Bowen, P.J. Ammonia for power. Progress Energy Combust. Sci. 2018, 69, 63-102. [CrossRef]

29. Frigo, S.; Gentili, R. Analysis of the behaviour of a 4-stroke Si engine fuelled with ammonia and hydrogen. Int. J. Hydrogen Energy 2013, 38, 1607-1615. [CrossRef] 
30. Gross, C.W.; Kong, S.-C. Performance characteristics of a compression-ignition engine using direct-injection ammonia-DME mixtures. Fuel 2013, 103, 1069-1079. [CrossRef]

31. Lan, R.; Tao, S. Ammonia as a Suitable Fuel for Fuel Cells. Front. Energy Res. 2014, 2. [CrossRef]

32. Mørch, C.S.; Bjerre, A.; Gøttrup, M.P.; Sorenson, S.C.; Schramm, J. Ammonia/hydrogen mixtures in an SI-engine: Engine performance and analysis of a proposed fuel system. Fuel 2011, 90, 854-864. [CrossRef]

33. Pochet, M.; Truedsson, I.; Foucher, F.; Jeanmart, H.; Contino, F. Ammonia-Hydrogen Blends in Homogeneous-Charge Compression-Ignition Engine. SAE Tech. Pap. 2017. [CrossRef]

34. Ryu, K.H.; Zacharakis-Jutz, G.; Kong, S.-C. Effects of Fuel Compositions on Diesel Engine Performance Using Ammonia-DME Mixtures. SAE Tech. Pap. 2013. [CrossRef]

35. Hansson, J.F.E.; Brynolf, S. On the Potential of Ammonia as Fuel for Shipping-A Synthesis of Knowledge; Lighthouse-Hållbar Sjöfart: Gothenburg, Sweden, 2020.

36. De Vries, N. Safe and Effective Application of Ammonia as a Marine Fuel; Delft University of Technology: Delft, The Netherlands, 2019.

37. Tronstad, T.; Åstrand, H.H.; Haugom, G.P.; Langfeldt, L. Study on the Use of Fuel Cells in Shipping; European Maritime Safety Agency (EMSA), DNV GL Maritime: Hamburg, Germany, 2017.

38. MAN Energy Solutions. Engineering the Future Two-Stroke Green-Ammonia Engine; MAN Energy Solutions: Copenhagen, Denmark, 2019.

39. Fertecon. Ammonia Market Report. 6 June 2019. Available online: https://agribusinessintelligence.informa.com/ products-and-services/data-and-analysis/fertecon/ammonia-market-report (accessed on 12 March 2020).

40. Hochman, G.G.A.; Felder, F.A.; Mayer, J.; Miller, A.; Holland, P.L. The Potential Economic Feasibility of Direct Electrochemical Nitrogen Reduction as a Route to Ammonia; ChemRxiv: New Jersey, NJ, USA, 2019.

41. Olmer, N.C.; Roy, B.; Mao, X.; Rutherford, D. Greenhouse Gas Emissions from Global Shipping, 2013-2015; International Council on Clean Transportation: Washington, DC, USA, 2017.

42. Lehtveer, M.; Brynolf, S.; Grahn, M. What Future for Electrofuels in Transport? Analysis of Cost Competitiveness in Global Climate Mitigation. Environ. Sci. Technol. 2019, 53, 1690-1697. [CrossRef] [PubMed]

43. Grahn, M.; Azar, C.; Williander, M.I.; Anderson, J.E.; Mueller, S.A.; Wallington, T.J. Fuel and Vehicle Technology Choices for Passenger Vehicles in Achieving Stringent CO2 Targets: Connections between Transportation and Other Energy Sectors. Environ. Sci. Technol. 2009, 43, 3365-3371. [CrossRef] [PubMed]

44. Lövdahl, J.; Magnusson, M. Evaluation of Ammonia as a Potential Marine Fuel; Department of Mechanics and Maritime Technology, Chalmers University of Technology: Gothenburg, Sweden, 2019.

45. Van Biert, L.; Godjevac, M.; Visser, K.; Aravind, P.V. A review of fuel cell systems for maritime applications. J. Power Sources 2016, 327, 345-364. [CrossRef]

46. Brunelli, M. Introduction to the Analytic Hierarchy Process; Springer International Publishing: Cham, Switzerland; New York, NY, USA; Dordrecht, The Netherlands; London, UK, 2015.

47. Saaty, T.L. Decision making with the analytic hierarchy process. Int. J. Serv. Sci. 2008, 1, 83-98. [CrossRef]

48. Månsson, S. Prospects for Renewable Marine Fuels; Chalmers University of Technology: Gothenburg, Sweden, 2017.

49. Bengtsson, S.A.K.; Ellis, J.; Haraldsson, L.; Ramne, B.; Stefenson, P. Criteria for Future Marine Fuels. In Proceedings of the IAME 2012 Conference, Taipei, Taiwan, 6-8 September 2012.

50. Danish Maritime Authority. North European LNG Infrastructure Project-A Feasibility Study for an LNG Filling Station Infrastructure and Test of Recommendations; The Danish Maritime Authority: Copenhagen, Denmark, 2012.

51. Moniz, E.J.H.D.; Meggs, A.J.M. The Future of Natural Gas-An Interdisciplinary MIT Study; Massachusetts Institute of Technology: Cambridge, MA, USA, 2012.

52. Schnitkey, G. Fertilizer Costs in 2017 and 2018. Farmdoc Daily, 11 July 2017.

53. Economic Research Service. All Fertilizer Use and Price Tables in a Single Workbook. Available online: https://www.ers.usda.gov/data-products/fertilizer-use-and-price/ (accessed on 28 November 2019).

54. Nelissen, D.; Faber, J.; Veen, R.v.d.; Grinsven, A.v.; Shanthi, H.; Toorn, E.v.d. Availability and Costs of Liquefied Bio- and Synthetic Methane-The Maritime Shipping Perspective; CE Delft: Delft, The Netherlands, 2020.

55. Anderson, M.; Salo, K.; Fridell, E. Particle- and Gaseous Emissions from an LNG Powered Ship. Environ. Sci. Technol. 2015, 49, 12568-12575. [CrossRef] 
56. Brynolf, S.; Fridell, E.; Andersson, K. Environmental assessment of marine fuels: Liquefied natural gas, liquefied biogas, methanol and bio-methanol. J. Clean. Prod. 2014, 74, 86-95. [CrossRef]

57. Gilbert, P.; Walsh, C.; Traut, M.; Kesieme, U.; Pazouki, K.; Murphy, A. Assessment of full life-cycle air emissions of alternative shipping fuels. J. Clean. Prod. 2018, 172, 855-866. [CrossRef]

58. Verbeek, R.K.; Mensch, P.V.; Wulffers, C.; Beemt, B.v.d.; Fraga, F. Environmental and Economic Aspects of Using LNG as a Fuel for Shipping in The Netherlands; TNO: Delft, The Netherlands, 2011.

59. Lowell, D.W.; Lutsey, N. Assessment of the Fuels Cycle Impacts of Liquefied Natural Gas as Used in International Shipping; The International Council on Clean Transportation: Washington DC, WA, USA, 2013.

60. Posch, M.; Seppälä, J.; Hettelingh, J.-P.; Johansson, M.; Margni, M.; Jolliet, O. The role of atmospheric dispersion models and ecosystem sensitivity in the determination of characterisation factors for acidifying and eutrophying emissions in LCIA. Int. J. Life Cycle Assess. 2008, 13, 477-486. [CrossRef]

61. IES. Characterisation factors of the ILCD Recommended Life Cycle Impact Assessment methods -Database and Supporting Information; European Commission, Joint Research Centre, Institute for Environment and Sustainability: Luxembourg, 2012.

62. Bicer, Y.; Dincer, I. Environmental impact categories of hydrogen and ammonia driven transoceanic maritime vehicles: A comparative evaluation. Int. J. Hydrogen Energy 2018, 43, 4583-4596. [CrossRef]

63. Kramer, K.J.; Moll, H.C.; Nonhebel, S. Total greenhouse gas emissions related to the Dutch crop production system. Agric. Ecosyst. Environ. 1999, 72, 9-16. [CrossRef]

64. Wood, S.; Cowie, A. A Review of Greenhouse Gas Emission Factors for Fertilizer Production; Cooperative Research Centre for Greenhouse Accounting: Research and Development Division, State Forests of New South Wales; NSW Department of Primary Industries: Armidale, Australia, 2004.

65. Zamfirescu, C.; Dincer, I. Ammonia as a green fuel and hydrogen source for vehicular applications. Fuel Process. Technol. 2009, 90, 729-737. [CrossRef]

66. Bartels, J.R. A Feasibility Study of Implementing an Ammonia Economy; Iowa State University: Ames, IA, USA, 2008.

67. Reiter, A.J.; Kong, S.-C. Combustion and emissions characteristics of compression-ignition engine using dual ammonia-diesel fuel. Fuel 2011, 90, 87-97. [CrossRef] 